\title{
蛍光 $\mathrm{X}$ 線による $\mathrm{Al}$ 膜厚測定
}

\author{
誉田 忠義* ·奥井 芳子* . 佐藤泰久 ${ }^{* *}$. 吉田 正道*
}

（受付 1990 年 8 月 27 日, 掲載決定1990年11月10日）

\author{
Thickness Measuerments of Al Films with X-ray Fluorescence \\ Tadayoshi HONDA, Yoshiko OKUI, \\ Yasuhisa SATO and Masamichi YOSHIDA \\ *(Fujitsu Limited, 1015, Kamikodanaka Nakahara-Ku, Kawasaki 211) \\ **(Fujitsu Laboratories Ltd, 10-1, Morinosato-Wakamiya, Atsugi 243-01)
}

(Received August 27, 1990, Accepted November 10, 1990)

\begin{abstract}
The thickness of $\mathrm{Al}$ thin films on $1000 \AA \mathrm{SiO}_{2}$ was estimated by using X-ray fluorescence (XRF). It was found that when the films were less than $1000 \AA$ thick, the number of $\mathrm{Al}$ XRF counts was directly proportional to the $\mathrm{Al}$ thickness. Therefore, $\mathrm{Al}$ thickness is given by $t=a(I f-B g)$ within an error of $3.0 \%$, where $a$ and $B g$ are constant and background noise, and If is the $\mathrm{Al} \mathrm{XRF}$ count. In the $\mathrm{Al}$ film thicknes range of $2000 \AA$ to $1.2 \mu \mathrm{m}, \mathrm{XRF}$ counts vs. $\mathrm{Al}$ thickness becomes nonlinear due to $\mathrm{Al}$ self-absorption. The $\mathrm{Al}$ thickness was given by $t=-a \cdot \ln (1-(\operatorname{If}-\operatorname{Bg} / \operatorname{Imax}))$, where Imax is maximum value measured by $\mathrm{Al}$ XRF. The maximum relative error was 1.6\%. However, for the Al film thickness range of $1000 \AA$ to $2000 \AA$, the relative error was $9.7 \%$.
\end{abstract}

\section{1. まえがき}

超 LSI の微細化に伴い, $\mathrm{Al}$ 配線に対する信頼性が強 く要求されてきており，配線材料として $\mathrm{Al}$ 配線の合金 化, $\mathrm{Al}$ 層と他メタル層への積層化が進められている ${ }^{1)}$. 配線の積層化には, $\left.\mathrm{AlSi} / \mathrm{TiN} / \mathrm{Ti}^{2}\right), \mathrm{Al} / \mathrm{TiN} / \mathrm{Al} / \mathrm{Poly} \mathrm{Si} /$ $\left.\mathrm{P}-\mathrm{Si}^{3}\right)$ などが提案され，いずれも最下層の $\mathrm{Ti}, \mathrm{Al}$ は基板 とのコンタクト形成やシリサイド化に, 数十〜数百 の膜厚が用いられている. 最下層 $\mathrm{Ti}, \mathrm{Al}$ の膜の厚さが 薄い場合コンタクト抵抗が大きくなり，また厚い場合 $\mathrm{Si}$ の吸い上げによってリークを起こす。このため膜厚 を適正に制御することが必要で，これには非破壊・非接 触の薄膜モニタリング法の確立が要求される.

メタル膜厚測定法としては, 破壊法の触針式走査法, 走査型電子顕微鏡法（断面 $\AA-S E M$ 法）, 透過型電子顕 微鏡法（断面 TEM 法）帛）たは非破壊法の蛍光 X 線分

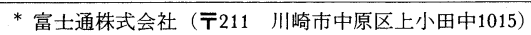

** 富士通研究所 (广243-01 神奈川県厚木市森の里若宮10番 1号)
析法5,6)などがある。触針式走査法は試料作成に時間が かかるものの, $1000 \AA$ ○湝い膜の測定が可能であ るため, 一般的に利用されている. しかし, 振動, 表面 あらさなどの影響を受けやすく薄い膜では䛊差が大きく なる。また断面 A-SEM 法, 断面 TEM 法などは薄い膜 を精度よく測定できるが，試料作成に時間を要するため 使用が限定される。一方, 蛍光 $\mathrm{X}$ 線分析法は検量線法 を用いることにより, 非破壊で測定ができ, 測定時間が 短く繰り返し精度がよいため, 最近利用されるようにな ってきた。

蛍光 X 線分析法は試料に一次 X 線を照射したときに 励起される特性 X 線を利用する. 特性 X 線は元素に固 有な波長（エネルギー）を有し，その強度が原子数に比 例するため, 定性, 定量分析掞よび検量線作成によって 薄い膜の膜厚測定ができる. エネルギー分布測定は分光 結晶を用いた波長分散型 (WDS) と $\mathrm{Si}(\mathrm{Li})$ 半導体検出 器を用いたェネルギー分散型 (EDS) があるが, 一次 $\mathrm{X}$ 線のコリメートの点から効率の高い EDS が多く用い 
られている7)。 しかし, EDS 蛍光 X 線分析法はエネル ギー分解能が悪いため, $\mathrm{Al} / \mathrm{Si}$ 系のように近接したエネ ルギーの元素を測定する場合バックグランドが大きくな り， $\mathrm{S} / \mathrm{N}$ が悪くなる。したがって，一般に Al 膜厚の測 定は基板の蛍光 $\mathrm{X}$ 線強度を測定する吸収法を用いる. このため, 薄い $\mathrm{Al}$ の膜厚測定が困難となる.

一方，WDS は土ネルギー分解能が良いため, $\mathrm{Al} / \mathrm{Si}$ 系でも薄い $\mathrm{Al}$ の膜厚測定できる。そこで， $\mathrm{Al} / \mathrm{SiO}_{2}$ 系 の膜厚測定を $\mathrm{Al}$ 密度が一定と仮定し, WDS 蛍光 $\mathrm{X}$ 線 分析法を用いた重量法によって検討した。 その結果， $\mathrm{Al}$ 膜厚の測定で, 薄い膜厚領域でも測定誤差を小さく 出来ることを見出したので報告する.

\section{2. 実験方法}

\section{1 装置および測定条件}

蛍光 X 線装置には波長分散型リガク製 $3620, \mathrm{X}$ 線管 球には $\mathrm{Rh}$ 対陰極を使用した。 また一次 $\mathrm{X}$ 線の引出し 口の空材として，薄い膜の測定に適したベリリウム空を

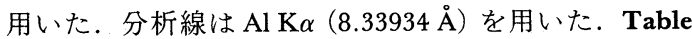
1 に測定条件を示す.

$\mathrm{Al}$ 膜厚は厚い膜（ここでは膜厚 $1000 \AA$ 以上の膜を言 5）の場合，触針式の Sloan 社製 Dektak II を使って $\mathrm{Al}$ 段差により膜厚を測定した．薄い膜については原子吸光 光度計で $\mathrm{Al}$ 膜重量を求め膜厚を換算し, その精度を比 較した。

\section{2 試 料}

実験に使用した pure $\mathrm{Al}$ は 6 インチ $\phi\left(173 \mathrm{~cm}^{2}\right)$ シリ コンウェー八上に, Si 熱酸化膜 $1000 \AA$ 成長後, スパッ タによって基板加熱なしで堆積した．スパッタ条件は $\mathrm{Ar}$ の圧力, 流量をそれぞれ $3 \times 10^{-3}$ Torr $\left(4 \times 10^{-1} \mathrm{~Pa}\right), 40 \mathrm{socm}$ とし，パワーと時間を変えて厚さが $50 \AA ̊ 2 \sim 20 \mu \mathrm{m}$ の Al の膜厚を用意した。 パワーは薄い膜で $0.6 \mathrm{kw}$ 前後，厚 い膜で $6 \mathrm{kw}$ 前後を使用した。

Table 1 Instrumental parameters

Rh tube

Analytical: line used $\mathrm{Al} \mathrm{K} \alpha$

PET: penta-erythritol $\left(\mathrm{C}\left(\mathrm{CH}_{2} \mathrm{OH}\right)_{4}\right)$

F-PC: gas flow proportional counter

Measured area: $30 \mathrm{~mm} \phi$

\begin{tabular}{c|l}
\hline Parameters & Values \\
\hline Voltage & $40 \mathrm{kV}$ \\
Current & $70 \mathrm{~mA}$ \\
Crystal & PET \\
Detector & F-PC \\
Counting Time & $10 \mathrm{~s}$ \\
\hline
\end{tabular}

\section{3. 実験 結果}

\section{1 測定装置の誤差}

蛍光 $\mathrm{X}$ 線分析は膜厚を測定する場合, 検量線法を使 用する．検量線法は測定した膜厚の精度に大きく影響を 及ぽすため, 正確度が要求される。そこで測定に用いた 装置の繰り返し精度を調べた。

\section{1 .1 触針式段差測定の精度}

触針式段差測定器は較正用標準を使って定期的に較正 するが，今回，薄い膜の測定では，熱酸化膜にエッチン グで段差を形成し，これを用いて較正をした。な拉測定 はエリプソメータを基準としだ).

Fig. 1 は熱酸化膜500〜6500 ̊̊ュリプソメータと触 針式で測定した膜厚の差を示す．触針式で測定した膜厚 はエリプソメータで測定した值に対して， $5.6 \times 10^{2} \AA$ の 薄い膜では $2.0 \times 10 \AA(3.6 \%)$ 薄い值を示すが， $6.00 \times$ $10^{3} \AA$ の厚い膜では $1.3 \times 10^{2} \AA(2.2 \%)$ 厚い值を示す. したがって，触針式で測定した膜厚の誤差は厚い膜では 小さく，薄い膜で大きいことがわかる．これは，触針式 で測定した場合の許容の範囲内 $(< \pm 5 \%)$ であるから， 触針式による測定値をそのまま膜厚とした，また，以下 の実験の換算膜厚には厚い膜を使用した。

Fig. 2 は膜厚 $8500 \AA ̊$ の同一試料を触針式によって10 回繰り返し測定した結果である. その結果, 標準偏差は $115.8 \AA$ 只，繰り返し測定誤差は $1.4 \%$ となった。

\section{1 .2 蛍光 $\mathrm{X}$ 線強度の精度}

蛍光 $\mathrm{X}$ 線の $\mathrm{X}$ 線検出系にガスフロ一型比例計数管 （10\%×タン $/ 90 \%$ アルゴン）とアンプ系が使用されてい る. これらの検出系には経時変化があるため, 出力パル スの大きさ（波高值）が変わり, 蛍光 $\mathrm{X}$ 線強度に変動 がある。

Fig. 3 は月日を変えて $\mathrm{Al}$ 強度を 3 回測定した結果で ある. $\mathrm{Al}$ 強度は測定点につき10回繰り返した平均值の

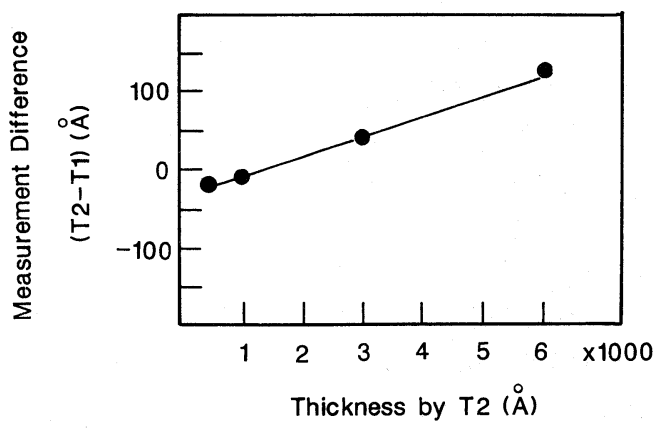

Fig. $1 \mathrm{SiO}_{2}$ thickness measured with a stylus profilometer (T1) and an ellipsometer (T2). 


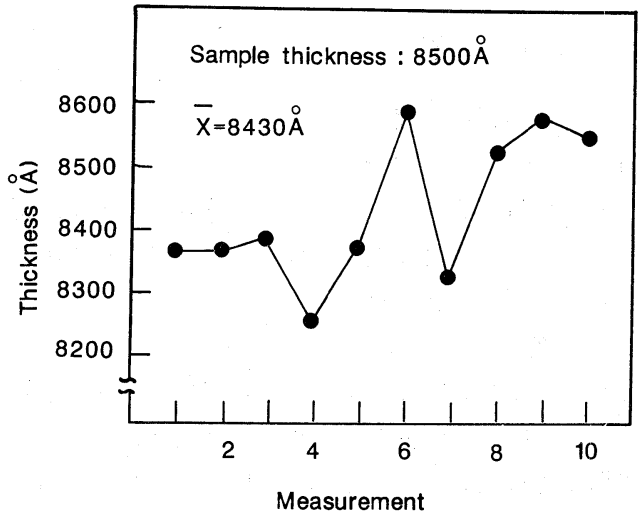

Fig. 2 Thickness vs. number of times measured with a stylus profilometer.

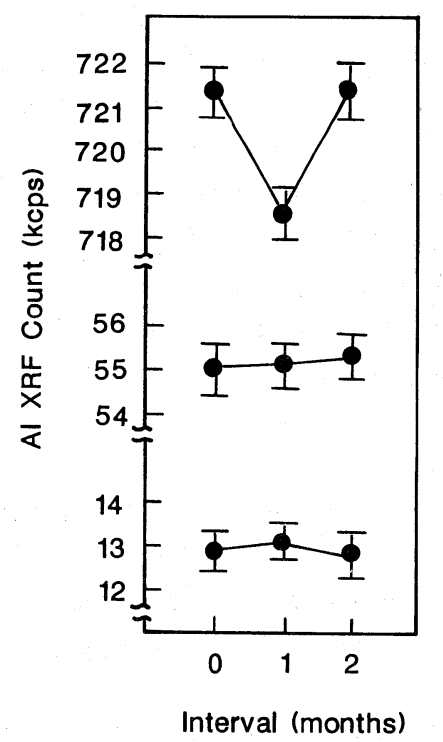

Fig. 3 Fluctuation of $\mathrm{Al}$ XRF count measured once a month for three diffrent thickness Al films.

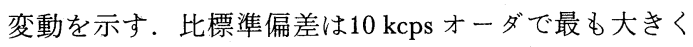
なり，測定誤差は $0.8 \%$ となった。したがって，測定装 置による䛊差は触針式では大きく, 蛍光 X 線で小さい

\section{ことがわかる。}

\section{2 膜重量からの膜厚計算}

薄い膜の測定に触針を用いると誤差が大きくなるた め, 膜厚を重量換算で求めた。平均膜厚と膜重量の関係 は次式で示される.

$$
T=W /(S \times \rho)
$$

ここで $T$ は平均膜厚, $W$ は膜重量, $\rho$ は密度, $S$ は面

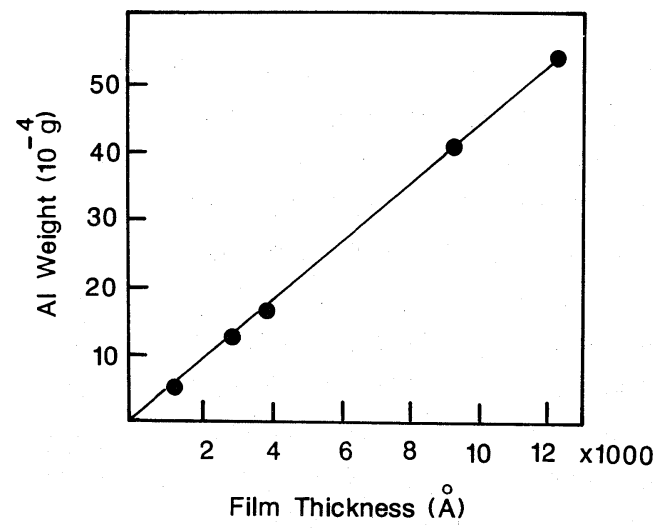

Fig. 4 Weight vs. film thickness for $\mathrm{Al}$ films.

積である. $\mathrm{Al}$ の密度は正確に求めることが困難なため, 膜厚によらず一定と仮定すると膜厚は膜重量より求めら れる．膜重量は薄い膜の場合には原子吸光，厚い膜の場 合には精密天秤を用いて測定した，そこで膜重量と膜厚 の相関を調べた。

\section{2 .1 膜重量の測定}

$\mathrm{Al}$ の膜重量の測定に当たり, 精密天秤でも測定でき る厚さ $1 \mu \mathrm{m}$ の同一 pure $\mathrm{Al}$ 膜を精密天秤と原子吸光を 用いて比較測定を行った。その結果, 膜重量は精密天秤 と原子吸光でそれぞれ $5.37 \times 10^{-2} \mathrm{~g}, 5.365 \times 10^{-2} \mathrm{~g}$ とな り, この両者はよく一致した. 以降, 原子吸光で求めた 膜重量は精密天秤で求めた膜重量と同等に信頼して取り 扱った。

次に, $\mathrm{SiO}_{2} 1000 \AA$ 上飞 $\mathrm{Al}$ を $50 \AA \sim 1 \mu \mathrm{m}$ の厚さ推積 して， $\mathrm{SiO}_{2}$ に侵入した $\mathrm{Al}$ 量を原子吸光で測定した。 そ の結果，極微量の $\mathrm{Al}$ が $\mathrm{SiO}_{2}$ に侵入していた。 その量は 厚さおよび堆積パワーによる傾向は見られず， $\mathrm{Al}$ 重量 で0.7〜 $1.9 \times 10^{-6} \mathrm{~g}, \mathrm{Al}$ 換算膜厚で $0.16 \sim 0.44 \AA$ となり, 膜厚測定には影響しない範囲の量であることがわかっ た.

\section{2 .2 膜厚換算方法}

式(1)で密度を一定とすると, 原子吸光で求めた平均 膜厚 $T 2$ は次式より求められる.

$$
T 2=(W 2 / W 1) \times T 1
$$

ここで $W 1$ は精密天秤より求めた厚い膜の重量, $W 2$ は原子吸光分析で求めた薄い膜の重量, $T 1$ は触針 式で測定した厚い膜の膜厚を示す。 $W 1, T 1$ は測定の結 果, 次の值となった。 $W 1=5.33 \times 10^{-2} \mathrm{~g}, T 1=1.235 \times$ $10^{4} \AA$.

Fig. 4 は $\mathrm{Al}$ 膜重量（W2）とウェー八内 5 点の平均膜 厚（T1）の関係である. 膜厚々膜重量は比例し, $\mathrm{Al}$ 膜 


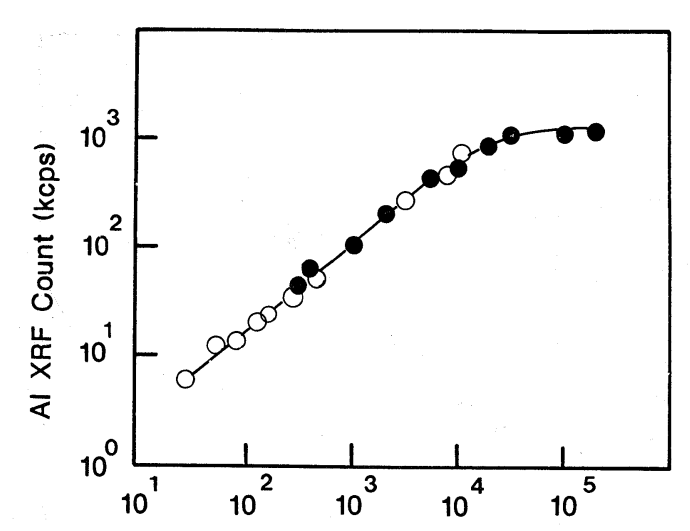

Film Thickness $(\stackrel{\circ}{)}$

Fig. 5 X-ray fluorescence vs. Al film thickness: (O) measured by gravimetric method; ( ) measured with a stylus profilometer.

密度に再現性があることがわかる.

\section{3 検量線}

Fig. 5 は $\mathrm{Al}$ 膜厚と蛍光 $\mathrm{X}$ 線強度の関係を示す. $\mathrm{Al}$ 膜厚は触針式によって測定した膜厚と原子吸光で求めた 重量を換算した膜厚で，それぞれ記号・，○で示した。 蛍光 $\mathrm{X}$ 線強度は膜厚の増加とともに大きな値となるが, $5 \mu \mathrm{m}$ 以上の膜厚で飽和し，臨界厚が $5 \mu \mathrm{m}$ であること を示している. その時の強度は $1225 \mathrm{kcps}$ となっている. これは, 試料が十分厚い時の蛍光 X 線強度である.

\section{4. 考察}

虽光 $\mathrm{X}$ 線による膜厚測定では, 一次 $\mathrm{X}$ 線によって発 生した蛍光 X 線の膜自身による吸収と一次 X 線によっ て励起された他元素の $\mathrm{X}$ 線によって励起される強調効 果8)考慮する必要がある。

Fig. 5 から蛍光 $\mathrm{X}$ 線強度は $\mathrm{Al}$ 膜の増加とともに勾配 が減衰し, $\mathrm{Al}$ 膜によるX 線の吸収が起こっていること がわかる.ここでは, 初めに吸収があるときの検出され る蛍光 X 線強度について考察し, 吸収の影響ができる 膜厚を見積もる。

蛍光 $\mathrm{X}$ 線強度の厚さによる变化を一次 $\mathrm{X}$ 線によって 発生する蛍光 $\mathrm{X}$ 線強度と吸収効果のみにより求めると 膜厚 $t$ に打ける強度 If は次式となる ${ }^{9)}$.

$$
I f=I \max (1-\exp (-\mu \rho t)
$$

ここで $I \max$ は試料が十分厚い時の蛍光線強度であ り, 入射 $\mathrm{X}$ 線の強度, 取り出し角执よびみかけの質量 吸収係に依存する。 $\rho$ は試料の密度 $\left(\mathrm{g} / \mathrm{cm}^{3}\right), \mu$ はみか けの質量吸収係数 $\left(\mathrm{cm}^{2} / \mathrm{g}\right)$ を表す。式(3)は膜が薄い 時には次式となる。
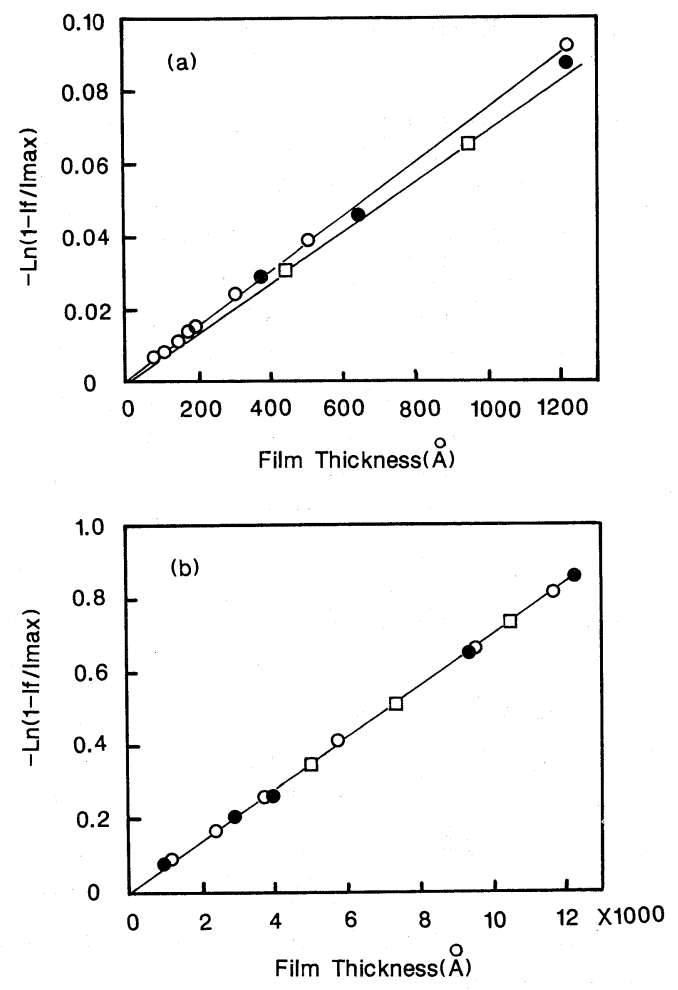

Fig. 6 Relationship between thickness and $-L n(1-I f / \operatorname{Imax})$ : (a) thin film; (b) thick film. (O) measured by gravimetric method, ( $\bullet$ measured with a stylus profilometer, (口) caluculated by theoretical formula.

$$
I f=I \max \mu \rho t
$$

したがって, 膜が薄い場合, 蛍光 X 線強度は膜厚に 比例する.

次に，測定結果に影響のでる厚さを実験結果より求め る。吸収を考慮した場合，式(3)は

$$
-\ln (1-I f / I \max )=\mu \rho t
$$

となり, $-\ln (1-I f / I \max )$ が膜厚 $t$ に比例する。これ にFig. 5 に示した蛍光X線強度, 膜厚およびI $\max =1225 \mathrm{kcps}$ を代入すると，Fig. 6(a)，(b)のように なる. $\rho(\mathrm{Al})=2.70 \mathrm{~g} / \mathrm{cm}^{3}$ として, Fig. 6(b)のグラフの 傾きから $\mu=2.60 \times 10^{3} \mathrm{~cm}^{2} / \mathrm{g}$ を得た. $I \max , \rho, \mu$ に前 述の数值を入れて, バックグランドを補正すると式(5) は

$$
t(\AA)=-1.424 \times 10^{4} \cdot \ln (1-(I f-7.1) / 1225)(6)
$$

となる。また，吸収を考慮しない場合， $\mu$ はFig. $6(\mathrm{a})$ の重量法より求めたグラフ（○）の傾きから $\mu=2.84 \times$ $10^{3} \mathrm{~cm}^{2} / \mathrm{g}$ を得た。これは吸収を考慮した場合より大き な值となっているが, 強調効果の影響と考える.I max, 
Table 2 Relative erorr of measured thickness with XRF

\begin{tabular}{c|c|c|c}
\hline \hline $\begin{array}{c}\text { Thickness } \\
(\AA)\end{array}$ & $\begin{array}{c}\text { Al XRF } \\
\text { count } \\
(\mathrm{kcps})\end{array}$ & $\begin{array}{c}\text { Thickness }(\AA) \\
\text { by } \\
\text { Formula }(6)\end{array}$ & $\begin{array}{c}\text { Thickness }(\AA) \\
\text { by } \\
\text { Formula }(7)\end{array}$ \\
\hline 100 & 16.1 & $105(+5.0 \%)$ & $97(-3.0 \%)$ \\
300 & 35.1 & $329(+9.7 \%)$ & $303(+1.0 \%)$ \\
1000 & 97.9 & $1097(+9.7 \%)$ & $983(-1.7 \%)$ \\
1200 & 110.9 & $1267(+5.6 \%)$ & $1123(-6.3 \%)$ \\
2000 & 170.3 & $2031(+1.6 \%)$ & $1763(-11.9 \%)$ \\
3000 & 240.6 & $3012(-0.4 \%)$ & $2530(-15.7 \%)$ \\
10000 & 623.0 & $9950(-0.5 \%)$ & $6670(-33.3 \%)$ \\
\hline
\end{tabular}

$\rho, \mu$ に前述の数値を入れてバックグランドを補正する 式(4)は同様に

$$
t(\AA)=10.82(\text { If }-7.1)
$$

となる。ここで得られた $\mu$ を装置の入身角 $\left(65^{\circ}\right)$ ，取り 出乙角 $\left(45^{\circ}\right)$ および一次 $\mathrm{X}$ 線 $(\mathrm{RhL} \alpha, \mathrm{L} \boldsymbol{\beta})$ と特性 $\mathrm{X}$ 線 $(\mathrm{AlK} \alpha)$ の質量吸収係数を用いて求めると $2.78 \times 10^{3}$ $\mathrm{cm}^{2} / \mathrm{g}$ となり，実験值と一致を示した。な敃質量吸収係 数に $\operatorname{RhL} \alpha=1.06 \times 10^{3}, \operatorname{RhL} \beta=9.20 \times 10^{2}, \quad \operatorname{AlK} \alpha=4.25$ $\times 10^{2} \mathrm{~cm}^{2} / \mathrm{g}$ を用いた ${ }^{10)}$.

吸収を考慮しなければならない膜厚はFig. 5 より各 膜厚に拈ける強度を比例内挿法によって求め, その強度 を補正式(6)，（7)に代入して計算した。その結果を

Table 2 に示す. Table 2 より吸収の効果は $2000 \AA ̊$ 以上 の膜厚で現れ, 触針式で求めた膜厚を蛍光 $\mathrm{X}$ 線で測定 すると相対誤差は最大で1.6\%となる。したがって, 吸 収効果の補正式 (6)は2000 ̊ 以上の膜厚に適用できる.

次に, 強調効果については実験による補正式について のみ考察する. Fig. 6(a)に示したよらに膜厚1200 ̊以 下ではー - n (1-If/I max) の值が, 式(5)から得られた直 線（ロ）よりも大きいことがわかる。これは，䖢光 $\mathrm{X}$ 線による膜厚の測定值が式 (5)から予想される值より大 きいことを示し，シリカーアルミナ系 ${ }^{11}$ に見られる強調 効果と同じである. 強調効果は一次 X 線以外に, 一次 $\mathrm{X}$ 線によって励起された他元素の特性 $\mathrm{X}$ 線によって蛍 光 X 線が励起されるために生ずる. 本実験では $\mathrm{Al}$ の吸 收端, $\mathrm{SiK} \alpha$ 線の波長がそれぞれ7.951 ̊, $7.126 \AA^{12)}$ で, $\mathrm{SiK} \alpha$ 線の波長が $\mathrm{Al}$ の吸収端より短いために, 一次 $\mathrm{X}$ 線以外に下地熱酸化膜および基板 $\mathrm{Si}$ からの $\mathrm{SiK} \alpha$ 線に よっても $\mathrm{AlK} \alpha$ 線が励起されるためである.

Fig. 7 亿膜厚 $500 \AA$ までの蛍光 X 線強度の膜厚依存 性を示すが，この膜厚範囲内では前述の強調効果は認め られるものの蛍光 $\mathrm{X}$ 線強度は膜厚に比例している. $\mathrm{Al}$ 膜厚と蛍光 $\mathrm{X}$ 線強度の相関係数は0.99939となり WDS

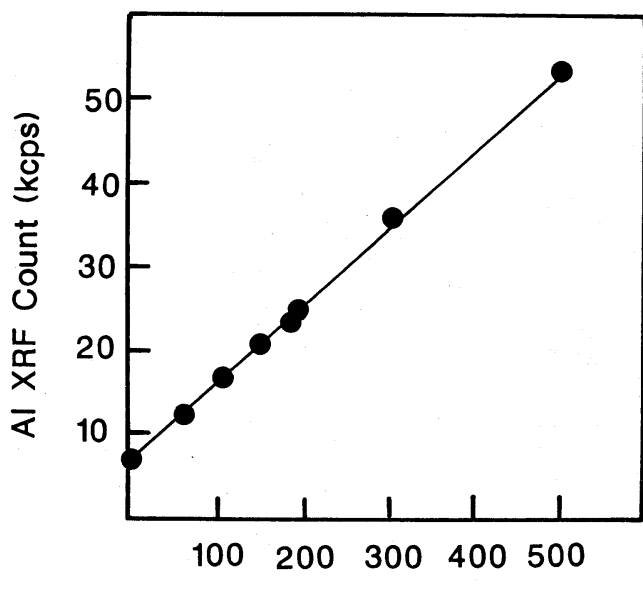

Film Thickness $(\AA)$

Fig. 7 Calibration curve for small thickness.

による蛍光 $\mathrm{X}$ 線法は膜厚測定に適していると考えられ る.この範曲内では, 本実験より, 膜厚 $t$ は蛍光 $\mathrm{X}$ 線 強度Ifに対し，補正式(7)で表せる。 また補正式(7)が 誤差 $3.0 \%$ 以内で適用できる膜厚は Table 2 に示すょう

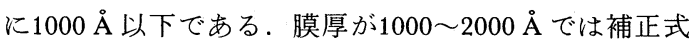
(6)，（7）より求めた膜厚は何れの場合にも誤差が大きく なる。これは, この膜厚の範囲内では, 強調効果の影響 が膜厚の増加とともに減少しているためである.

\section{5. と め}

蛍光 X 線分析法により $\mathrm{Si}$ 熱酸化膜 $1000 \AA$ 上の pure $\mathrm{Al}$ の膜厚測定を触針法と重量法と比較して検討した。 触針式にはSloanの社製の Dektak II を，また重量法に は原子吸光を用いた。 その結果, 次のことが明らかとな った。

(1) $\mathrm{Al}$ 膜厚が $1000 \AA$ 以下では虽光 $\mathrm{X}$ 線強度 If は, $\mathrm{Al}$ 膜厚 $t$ V比例し,

$t(\AA)=a(I f-B g)$ で表せる.この近似式を使うと 相対誤差は最大で $3.0 \%$ となる.

(2) $2000 \AA \sim 1.2 \mu \mathrm{m}$ では, 蛍光 $\mathrm{X}$ 線強度 If 身による吸収の影響がでて膜厚に比例しなくなる が，吸収の影響を考慮したときには，膜厚 $t$ は $t(\AA)=-a \cdot \ln (1-(I f-B g) / I \max )$

で表せ，このとき相対誤差は最大で1.6\%となる。

(3) $1000 〜 2000 \AA$ では, 膜厚の䛊差は $9.7 \%$ となる.

以上のことから $50 \AA ̊ 1.2 \mu \mathrm{m}$ までの広範囲では, 蛍 光 $\mathrm{X}$ 線強度測定によって, $\mathrm{Al}$ 膜厚が触針式段差法より も繰り返し誤差の幅が小さく測定でき, 特に $500 \AA$ 以下 の薄い領域でも測定が可能であることがわかった. 


\section{〔文献〕}

1) 舟木洋一 : NIKKEI MICRODEVICES (1986) No. 12, 85 .

2）中嶋英晴, 濱嶋俊樹, 菅野幸保: 第33回応用物理 学関連講演会 (1986) p. 503.

3) 名村 至, 秀島 修, 市川雅章, 倉橋敏男, 稲吉 勝幸 : 第33回応用物理学関連講演会 (1986) p. 503 .

4) Sheldon G. P. Lim, Doug Ridly: Solid State Technology (1983) No. 2, 99.

5）斉藤いほ方：表面技術４0（1989）190.
6) Stephen Ernst, Chang-Ou Lee, and Jen-Jiang Lee: J. Electrochem. Soc. SOLID-STATE SGIENCE AND TECHNOLOGY 135 (1988) 2111.

7）佐藤正雄：表面技術 40 （1989） 220.

8）日本学術振興会：薄膜ハンドブック (1983) p. 405

9) Toshio Shiraiwa and Nobutatsu Fujino: Japanese Journal of Applied Physics 5 (1966) No. 10, 886.

10) Roger Theisen und Dieter Vollath: Table of $X-$ Ray Mass Attenuation Coefficients (1967) p. 14.

11）柴田和秀, 新井智也訳 : 分析化学者のための $\mathrm{X}$ 線 分光分析（理学電機図書出版社, 1964） p. 221.

12）東京天文台編纂：理科年表（1978）物 p. 127. 